\title{
THE ASSOCIATION OF IGF2 WITH PRODUCTIVE TRAITS OF PIGS OF LARGE WHITE BREED IN THE ASPECT OF SEXUAL DIFFERENTIATION
}

\section{O.V. KOSTYUNINA ${ }^{1}$, S.S. KRAMARENKO ${ }^{2}$, N.A. SVEZHENTSEVA ${ }^{1}$, E.I. SIZAREVA ${ }^{1}$, N.A. ZINOVIEVA ${ }^{1}$}

${ }^{1}$ L.K. Ernst All-Russian Research Institute of Animal Husbandry, Federal Agency of Scientific Organizations, pos. Dubrovitsy, Podolsk Region, Moscow Province, 142132 Russia, e-mail kostolan@yandex.ru;

${ }_{2}^{2}$ Mykolayiv State Agrarian University, vul. Paris Commune, 9, Mykolayiv, 54020 Ukraine, e-mail kss0108@mail.ru Received September 11, 2015

\begin{abstract}
Marker-assisted selection is an attractive way to improve the economically important traits in domestic animals and particularly in pigs. Insulin-like growth factor 2 (IGF2) is one of the potentially important genetic marker for growth and carcass traits of pigs. The objective of our work was to study G3072A polymorphism of IGF2 gene in different pig breeds and to evaluate the effect of boar genotypes on productive traits of their offspring of different sexes. IGF2 polymorphism was studied in seven pig breeds including large white and their close related breeds Yorkshire and Edelswine (LW, $n=1247)$, Landrace (L, $n=934)$, Duroc (D, $n=642)$, Pietrain $(\mathrm{P}, n=87)$, Belorussian meat (BM, $n=37)$, Liven (LIV, $n=54)$, Estonian beckon (EB, $n=10)$, one synthetic line Body $(\mathrm{BD}, n=138)$ and one terminal cross $(\mathrm{TM}, n=66)$. Association studies were performed using data records of 5908 offspring (including 5015 gilts and 893 young boars) produced from twenty LW boars with known genotype for $I G F 2$. The following productive traits were evaluated: body weight at the end of growing period (BW, $\mathrm{kg}$ ), daily gain during entire growing period (DG, g), daily gain during early period from birth to $76.41 \pm 0.04$ days (DG1, g), daily gain during late period from $76.41 \pm 0.04$ to $170.23 \pm 0.05$ (DG2, g); the age at $100 \mathrm{~kg}$ ( $\mathrm{AGE}_{100 \mathrm{~kg}}$, days), average actual back fat thickness measured in four points at the end of growing period $(\mathrm{BF}, \mathrm{mm})$ and average back fat thickness calculated for the $100 \mathrm{~kg}$ body weight $\left(\mathrm{BF}_{100 \mathrm{~kg}}, \mathrm{~mm}\right)$. Significantly higher frequencies of the potentially «desired» $A$ allele and $A A$ genotype were observed in BD (0.986 and 0.971 , respectively), TM (0.977 and 0.955$), \mathrm{P}(0.966$ and 0.931$)$ and $\mathrm{D}(0.960$ and 0.921$)$. LW pigs were characterized by the intermediate values of allele $A(0.664)$ and genotype $A A$ frequencies (0.532). In EB, BM and $\mathrm{L}$ the frequencies of $A$ allele and $A A$ genotype varied from 0.250 to 0.363 and from 0.100 to 0.243 , respectively. We did not identify $A$ allele in local Russian LIV pig breed. Association studies showed high-significant tendency to increase of BW, DG1, DG2, DG, BF and $\mathrm{BF}_{100 \mathrm{~kg}}$ values and to decrease of $\mathrm{AGE}_{100 \mathrm{~kg}}$ values of both gilts and boars at the order of genotypes $G G \rightarrow A G \rightarrow$ $A A$. Calculations performed with additive-dominance model and two-way analysis of variance (ANOVA) showed the faster increasing (decreasing) above-mentioned traits in order of genotypes $G G \rightarrow A G \rightarrow A A$ in young boars comparing to gilts. Principal component (PC) analysis showed that first two PCs (PC1 and PC2) determine $76.23 \%$ of variability of the initial matrix for young boars and $82.49 \%$ for gilts. PC1 is highly associated with daily gains during the late growing period (for DG2: $r=0.501$ for young boars and 0.896 for gilts) and for the entire growing period (for DG: $r=$ 0.923 and 0.929 ), whereas PC2 is associated with the daily gains during early growing period (for DG1: $r=-0.709$ and -0.769). The additive (A) and dominant (D) components of the variability and effects of allele substitution calculated for PC1 were similar for both sexes: A $=0.290, \mathrm{p}<$ $0.001 ; \mathrm{D}=-0.064-$ in gilts and $\mathrm{A}=0.351, \mathrm{p}<0.001 ; \mathrm{D}=0.040-$ in young boars. We received significant values for PC2 in young boars only for dominant component $(A=0.085 ; \mathrm{D}=$ $0.177, \mathrm{p}<0.05)$, whereas in gilts it was only for additive component $(\mathrm{A}=0.094, \mathrm{p}<0.001 ; \mathrm{D}=$ $-0.031)$. The quantitative effects of IGF2 genotypes growing performance on the growth and carcass traits of pigs, and sex-dependent effect of marker genotypes on growing performance of pigs among growing periods should be taken in a point for development of programs of markerassisted selection utilizing $I G F 2$.
\end{abstract}

Keywords: pigs, Sus scrofa, large white breed, population, growing performance, QTL, ПЦР, mutation, IGF2. 
to quantitative trait loci (QTL) and their introduction into the selection and breeding programs is a promising way of a more effective genetic improvement of farm animals. Molecular genetic approach is especially useful if the traits have been used in a number of generations as the main breeding traits, and the potential of the traditional evaluation and selection has been almost fully implemented [1].

The intensity of growth (early maturity) is one of the main economically important traits in farm animals. Selection of this trait over several decades yielded pig lines with high weight gain. Thus, in Duroc pigs (breeding program of the Canadian Center for Swine Improvement, CCSI), the age of reaching the body weight of $100 \mathrm{~kg}$, which was over 180 days in 1980, decreased to 150 days in 2013 (according to testing 10,792 animals 53 herds) [2]. Further progress in breeding is related to the development of programs based on the identification and use of DNA markers associated with growth intensity [3]. Based on the effects on myogenesis and involvement in many processes of metabolism and differentiation, the insulin-like growth factor 2 (IGF2) is one of the potentially important genetic markers for growth and carcass traits in pigs [4-6]. It is localized in the distal end of pig chromosome 2 [7]. A considerable impact of the G3072A mutation in the intron 3 of IGF2 on the growth rate, muscle weight gain and fat deposition was established [8)] and repeatedly confirmed in different populations $[6,9-12]$. The $A \rightarrow G$ substitution came from Chinese pigs and penetrated into the Western commercial lines due to phenotypic expression [13]. It breaks the nuclear factor repressor binding site which results in a 3-fold postnatal overexpression of IGF2 mRNA in skeletal muscles in the pigs that have inherited this mutation from their fathers [8]. D. Gardan et al. [14] studied the effect of IGF2 genotype on adipocytes and subcutaneous tissues and confirmed that the IGF2 mRNA expression was higher in muscles (but not in subcutaneous tissues) in the pigs with inherited $A$ allele. They did not find any intergroup differences in the number of adipocytes, but noted a decrease in adipocyte size in the offspring of the boars with $A$ allele. The authors concluded that the IGF2 mutation promotes hypertrophy of muscle fibers and reduces the development of fat cells in subcutaneous tissue. In their study of the IGF2 effects on proteolytic and lipolytic enzyme activity, K. Van den Maagdenberg et al. [15] found that pigs with inherited father's $A$ allele had a relatively large weight at slaughter, which is probably associated with decreased protein degradation.

The advantage of IGF2 as the marker is the paternal nature of expression (maternal imprinting) which makes it possible to affect the productivity of the offspring, regardless of mothers' genotypes, as well as the positive impact of the $A$ allele, potentially desirable from the standpoint of fattening qualities, on reproductive performance [16].

Integration of $I G F 2$ as the marker in the selection and breeding programs should be preceded by a quantitative assessment of the effects of IGF2 genotype on the offspring productive performance (in a representative sample). Since young boars and gilts are used in the determination of the breeding value, its dependence on the animal gender is relevant.

The objective of our study was the allele pool characterization for IGF2 in different pig breeds and estimation of the impact of the fathers' IGF2 genotypes on productive performance of their offspring considering the gender (the Large White breed example).

Technique. The characterization of the allele pool of pigs for IGF2 was studied in 3215 animals belonging to the following breeds: large white (LW) and their close related breeds, the Large White, Yorkshire and Edelswine (26 groups, $n=1247)$, Landrace (L, 21 group, $n=934)$, Duroc ( $\mathrm{D}, 17$ groups, $n=642)$, Pietrain (P, 3 groups, $n=87)$, Belorussian Meat breed (BM, 1 group, $n=37)$, Liven (LIV, 1 group, $n=54)$, Estonian bacon breed (EB, 1 group, $n=10)$, as well as the Body synthetic line (BD, 1 group, $n=138)$ and one terminal cross 
(TM, 2 groups, $n=66$ ) (over 20 farms in different regions). Tissue samples were the material for the molecular genetic studies (ear tissue fragment). DNA was isolated using the Nextec reagent kit according to the manufacturer recommendations (Nexttec ${ }^{\mathrm{TM}}$ Biotechnologie $\mathrm{GmbH}$, Germany). IGF2 polymorphism in the G3072A position was determined by pyrosequencing by A.-S. Van Laere et al. [8].

Association study was performed using breeding data records of 5908 Large White pigs (including 5015 gilts and 893 young boars; genetic core, LLC Znamensky Breeding and Hybrid Center, Orel Province) produced from the boars $(n=20)$ with known genotype for IGF2. The following productive traits were evaluated at the end of growing period: body weight $(\mathrm{BW}, \mathrm{kg})$; the age at $100 \mathrm{~kg}\left(\mathrm{AGE}_{100 \mathrm{~kg}}\right.$, days); average actual back fat thickness measured in four points at the end of growing period $(\mathrm{BF}, \mathrm{mm})$ and average back fat thickness calculated for the $100 \mathrm{~kg}$ body weight $\left(\mathrm{BF}_{100 \mathrm{~kg}}, \mathrm{~mm}\right)$; daily gain during entire growing period (DG, g), and in the early growing period from 0 to $76.41 \pm 0.04$ days (DG1, g) and late growing period from 76.41 \pm 0.04 to $170.23 \pm 0.05$ (DG2, g).

The additive (A) and the dominant (D) components of the model were calculated as $\mathrm{A}=\bar{X}_{22}-\bar{X}_{11} ; \mathrm{D}=\bar{X}_{12}-\left(\bar{X}_{11}+\bar{X}_{22}\right) / 2$, where $\bar{X}_{11}, \bar{X}_{12}, \bar{X}_{22}$ are arithmetic means of evaluated productivity values for $G G, A G$, and $A A$ genotypes, respectively.

The level of significance for $\mathrm{A}$ and $\mathrm{D}$ was estimated using the multiple linear regression model: $Y=\mu+\mathrm{A} X_{1}+\mathrm{D} X_{2}+\mathrm{e}$, where $Y$ is productivity value; $\mu$ is general mean; $X_{1}$ is code variable which is -1 for $G G$ genotype, 0 for $A G$ genotype and +1 for $A A ; X_{2}$ is code variable which is 0 for $G G$ and $A A$ genotypes and +1 for $A G$ genotype; e is a random component.

The effects of $G$ and $A$ alleles were estimated as $\alpha_{1}=\mathrm{m}_{1}-\bar{X}, \alpha_{2}=\mathrm{m}_{2}-\bar{X}$, where $\mathrm{m}_{1}=\mathrm{p} \cdot \bar{X}_{11}+\mathrm{q} \cdot \bar{X}_{12}, \mathrm{~m}_{2}=\mathrm{p} \cdot \bar{X}_{12}+\mathrm{q} \cdot \bar{X}_{22}$ ( $\mathrm{p}$ and $\mathrm{q}$ is the frequency of alleles $G$ and $A$, respectively, $\bar{X}$ is overall arithmetic mean for the group). The effect of allelic sudstitution was calculated as $2^{-1} \cdot \alpha(G \rightarrow A)=\left(\alpha_{2}-\alpha_{1}\right) \cdot 2^{-1}$.

All calculations were made as described [17]. Statistical hypothesis of the similar relationship between productivity and IGF2 genotype in pigs of different genders was tested by two-factor analysis of variance (two-way ANOVA). Principal component analysis (PCA) was performed based on the correlation and covariance matrix of the seven studied productivity traits (for gilts and young boars separately) to detect latent traits that contribute mostly to the variability of pigs according to their genotype for locus IGF2. Statistica v. 6.0 software was used for calculations.

Results. The frequencies of desired $A$ allele were significantly higher in

1. Distribution of IGF2 allele frequencies in various breeds $\left(P \pm S_{p}\right)$

\begin{tabular}{|c|c|c|}
\hline Breed/cross & $A$ allele & $G$ allele \\
\hline BD & $0.986 \pm 0.007 \mathrm{f}, \mathrm{m}, \mathrm{p}, \mathrm{z}, \mathrm{D}, \mathrm{F}$ & $0.014 \pm 0.007 \mathrm{f}, \mathrm{m}, \mathrm{p}, \mathrm{z}, \mathrm{D}, \mathrm{F}$ \\
\hline TM & $0.977 \pm 0.013^{\mathrm{d}, 1, \mathrm{v}, \mathrm{x}, \mathrm{y}}$ & $0.023 \pm 0.013^{\mathrm{d}, \mathrm{l}, \mathrm{v}, \mathrm{x}, \mathrm{y}}$ \\
\hline $\mathrm{P}$ & $0.966 \pm 0.014 \mathrm{c}, \mathrm{k}, \mathrm{s}, \mathrm{t}, \mathrm{u}$ & $0.034 \pm 0.014 \mathrm{c}, \mathrm{k}, \mathrm{s}, \mathrm{t}, \mathrm{u}$ \\
\hline $\mathrm{D}$ & $0.960 \pm 0.005^{b}, \mathrm{j}, \mathrm{o}, \mathrm{p}, \mathrm{q}, \mathrm{r}$ & $0.040 \pm 0.005^{b, j, o, p, ~ q, ~ r ~}$ \\
\hline LW & $0.664 \pm 0.009^{a}, \mathrm{~b}, \mathrm{c}, \mathrm{d}, \mathrm{e}, \mathrm{f}, \mathrm{g}, \mathrm{h}$ & $0.336 \pm 0.009^{\mathrm{a}, \mathrm{b}, \mathrm{c}, \mathrm{d}, \mathrm{e}, \mathrm{f}, \mathrm{g}, \mathrm{h}}$ \\
\hline $\mathrm{L}$ & $0.363 \pm 0.013^{\mathrm{a}, \mathrm{j}, \mathrm{k}, \mathrm{l}, \mathrm{m}, \mathrm{n}}$ & $0.637 \pm 0.013^{\mathrm{a}, \mathrm{j}, \mathrm{k}, \mathrm{l}, \mathrm{m}, \mathrm{n}}$ \\
\hline BM & $0.338 \pm 0.055^{\mathrm{e}}, \mathrm{o}, \mathrm{s}, \mathrm{v}, \mathrm{z}, \mathrm{B}$ & $0.662 \pm 0.055^{\mathrm{e}}, \mathrm{o}, \mathrm{s}, \mathrm{v}, \mathrm{z}, \mathrm{B}$ \\
\hline EB & $0.250 \pm 0.097 \mathrm{~h}, \mathrm{n}, \mathrm{r}, \mathrm{u}, \mathrm{y}, \mathrm{F}, \mathrm{G}$ & $0.750 \pm 0.097 \mathrm{~h}, \mathrm{n}, \mathrm{r}, \mathrm{u}, \mathrm{y}, \mathrm{F}, \mathrm{G}$ \\
\hline LIV & $0.00 \mathrm{~g}, \mathrm{q}, \mathrm{t}, \mathrm{x}, \mathrm{B}, \mathrm{D}, \mathrm{G}$ & $1.00 \mathrm{~g}, \mathrm{q}, \mathrm{t}, \mathrm{x}, \mathrm{B}, \mathrm{D}, \mathrm{G}$ \\
\hline \multicolumn{3}{|c|}{$\begin{array}{l}\text { N o t e. BD - Body, TM - terminal cross, P - Pietrain, D - Duroc, LW - Large White and their close related } \\
\text { breeds (Large White, Yorkshire, Edelswine), L - Landrace, BM - Belorussian meat breed, EB - Estonian bacon } \\
\text { breed, LIV - Liven. Studied breeds are listed in descending order of the frequency of desired } A \text { allele for IGF2. } \\
\text { Differences between groups marked with the same letter are significant at } \mathrm{p} \leq 0.001 \text { for a, b, c, d, e, f, g, h, } \\
\mathrm{j}, \mathrm{k}, \mathrm{l}, \mathrm{m}, \mathrm{n}, \mathrm{o}, \mathrm{q}, \mathrm{r}, \mathrm{s}, \mathrm{t}, \mathrm{u}, \mathrm{v}, \mathrm{x}, \mathrm{y}, \mathrm{z}, \mathrm{B}, \mathrm{D}, \mathrm{F} \text {; at p } \leq 0.001 \text { for } \mathrm{p}, \mathrm{C} \text {; and at } \mathrm{p} \leq 0.05 \text { for I, w, A, E, G. }\end{array}$} \\
\hline
\end{tabular}

BD, P, D, and TM animals used as father forms at the second phase of hybridization (Table 1). LW pigs were characterized by the intermediate values which apparently was due to the breeding for both meat, fattening and on reproductive 
traits. Rather low frequencies of $A$ allele in L pigs and in the BM breed produced on the basis of Landrace, can be considered as a consequence of permanent selection on reproductive qualities. $A$ allele was not identified in the local LIV pig breed.

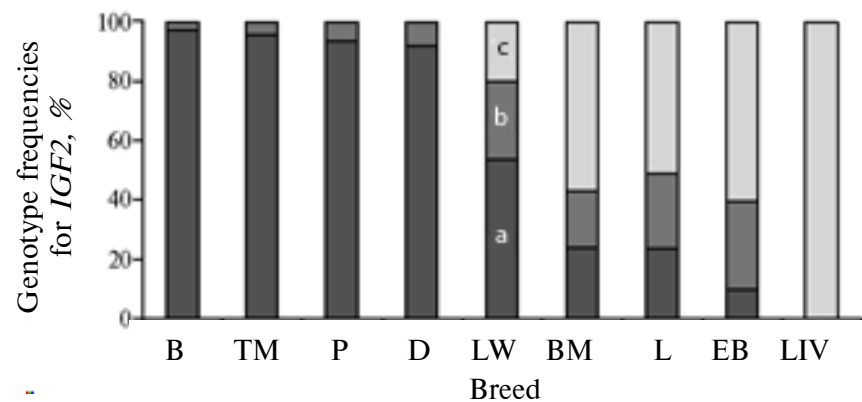

Fig. 1. Distribution of $A A$ (a), $A G$ (b) and $G G$ (c) genotype frequencies for $I G F 2$ in different pig breeds: BD - Body, TM terminal cross, P - Pietrain, D - Duroc, LW - Large White and their close related breeds (Large White, Yorkshire, Edelswine), BM - Belorussian meat breed, L - Landrace, EB - Estonian bacon breed, LIV - Liven. Studied breeds are listed in descending order of the frequency of desired $A A$ genotype.

Frequency of desired $A A$ genotype in father forms of BD, TM, P, and $\mathrm{D}$ was $38.9-42.3 \%$ higher compared to LW $(\mathrm{p}<0.001), 67.7-73.4 \%$ higher compared to $\mathrm{BM}$ and $\mathrm{L}(\mathrm{p}<0.001)$, and 82.1$87.1 \%$ higher compared to EB (p $<0,001)$ (Fig. 1).

The data on the distribution of allele and genotype frequencies suggest that breeding for meat and feeding traits performed in a number of generations contributed to the preferential fixation of $A$ allele in the populations of pig meat breeds and, on the contrary, leaching of the $G$ allele for IGF2.

Association study in Large White pigs demonstrated that productivity traits in the offspring (both gilts and boars) were largely determined by the IGF2 genotype of their fathers (Table 2). A high-significant tendency was shown to the increase of $\mathrm{BW}, \mathrm{DG} 1, \mathrm{DG} 2, \mathrm{DG}, \mathrm{BF}$ and $\mathrm{BF}_{100 \mathrm{~kg}}$ values and to the decrease of $\mathrm{AGE}_{100 \mathrm{~kg}}$ values in the order of genotypes as $G G \rightarrow A G \rightarrow A A$ (see Table 2).

2. The results of one-way ANOVA evaluating the effect of father's IGF2 genotype on the offspring productivity traits in Large White pigs

\begin{tabular}{|c|c|c|c|c|c|c|c|c|c|}
\hline \multirow{3}{*}{ Trait } & \multirow{3}{*}{ Gender } & \multicolumn{6}{|c|}{ Genotype } & \multirow{3}{*}{$F$} & \multirow{3}{*}{$\mathrm{p}$} \\
\hline & & \multicolumn{2}{|c|}{$G G(n=976)$} & \multicolumn{2}{|c|}{$A G(n=1046)$} & \multicolumn{2}{|c|}{$A A(n=2993)$} & & \\
\hline & & $\bar{X}$ & $S_{\bar{X}}^{-}$ & $\bar{X}$ & $S_{\bar{X}}^{-}$ & $\bar{X}$ & $S_{\bar{X}}^{-}$ & & \\
\hline \multirow[t]{2}{*}{ BW } & ㅇ & 100.9 & 0.32 & 105.3 & 0.33 & 109.0 & 0.21 & 211.1 & 0.0001 \\
\hline & $\hat{0}$ & 110.3 & 1.16 & 113.1 & 1.03 & 118.2 & 0.59 & 20.3 & 0.0001 \\
\hline \multirow[t]{2}{*}{ DG1 } & 우 & 441.6 & 1.55 & 450.8 & 1.54 & 454.8 & 0.97 & 24.2 & 0.0001 \\
\hline & $\sigma^{\lambda}$ & 458.0 & 5.09 & 456.2 & 3.82 & 472.5 & 2.30 & 8.2 & 0.0003 \\
\hline \multirow[t]{2}{*}{ DG2 } & 우 & 713.9 & 2.75 & 756.4 & 3.16 & 791.0 & 1.90 & 226.3 & 0.0001 \\
\hline & o & 802.0 & 10.33 & 857.4 & 27.80 & 922.9 & 23.18 & 3.5 & 0.0318 \\
\hline \multirow[t]{2}{*}{ DG } & 우 & 585.4 & 2.01 & 612.2 & 2.03 & 633.6 & 1.32 & 186.8 & 0.0001 \\
\hline & $\sigma^{2}$ & 640.0 & 6.71 & 657.5 & 6.48 & 692.0 & 4.39 & 18.1 & 0.0001 \\
\hline \multirow{2}{*}{$\mathrm{AGE}_{100 \mathrm{~kg}}$} & 우 & 170.6 & 0.53 & 163.1 & 0.51 & 157.8 & 0.30 & 226.5 & 0.0001 \\
\hline & $\sigma^{\lambda}$ & 156.1 & 1.68 & 152.9 & 1.46 & 145.4 & 0.78 & 21.5 & 0.0001 \\
\hline \multirow[t]{2}{*}{ BF } & 우 & 11.1 & 0.06 & 11.7 & 0.07 & 12.3 & 0.05 & 99.0 & 0.0001 \\
\hline & o & 11.1 & 0.23 & 12.2 & 0.23 & 12.8 & 0.12 & 16.2 & 0.0001 \\
\hline \multirow[t]{2}{*}{$\mathrm{BF}_{100 \mathrm{~kg}}$} & 우 & 11.0 & 0.04 & 11.1 & 0.05 & 11.2 & 0.03 & 9.0 & 0.0001 \\
\hline & $\sigma^{2}$ & 10.0 & 0.16 & 10.7 & 0.15 & 10.8 & 0.07 & 7.8 & 0.0005 \\
\hline
\end{tabular}

$\overline{\mathrm{N} \text { ot e. BW }}$ - body weight at the end of growing period, kg; DG1 - daily gain in the early growing period (from birth to $76.41 \pm 0.04$ days), g; DG2 - daily gain in the late growing period (from 76.41 \pm 0.04 to $170.23 \pm 0.05$ days), g; $\mathrm{DG}$ - daily gain at the end of growing period, g; $\mathrm{AGE}_{100 \mathrm{~kg}}$ - the age at $100 \mathrm{~kg}$, days; $\mathrm{BF}$ - average actual back fat thickness measured in four points at the end of growing period, $\mathrm{mm} ; \mathrm{BF}_{100 \mathrm{~kg}}-$ average back fat thickness calculated for the $100 \mathrm{~kg}$ body weight, $\mathrm{mm} . F$ is Fisher dispersion relation, $\mathrm{p}$ is a significance level.

Detailed analysis of the manifestations of productivity traits in the offspring depending on the father's genotype for IGF2 performed with additivedominance model showed the significance of the estimates for the additive component (both for gilts and young boars), although the degree of manifestation of this component was often higher in gilts (Table 3 ). 
3. Parameters of additive-dominance model of the dependence of productivity traits on the father's IGF2 genotype in Large White gilts and young boars

\begin{tabular}{|c|c|c|c|c|c|c|}
\hline \multirow{2}{*}{ Trait } & \multicolumn{3}{|c|}{ Gilts } & \multicolumn{3}{|c|}{ Young boars } \\
\hline & A & $\mathrm{D}$ & $2^{-1} \cdot \alpha(G \rightarrow A)$ & A & $\mathrm{D}$ & $2^{-1} \cdot \alpha(G \rightarrow A)$ \\
\hline BW & $4.068^{* * *}$ & $0.402^{\text {ns }}$ & 1.951 & $3.950^{*}$ & $-0.961^{\mathrm{ns}}$ & 2.277 \\
\hline DG1 & $6.581^{* * *}$ & $2.574^{\mathrm{ns}}$ & 2.771 & $7.246^{*}$ & $-9.019^{*}$ & 6.034 \\
\hline DG2 & $38.532^{* * *}$ & $3.908^{\mathrm{ns}}$ & 18.461 & $60.442 *$ & $-3.131^{\mathrm{ns}}$ & 31.567 \\
\hline DG & $24.105^{* * *}$ & $2.685^{\mathrm{ns}}$ & 11.501 & $25.997^{* * *}$ & $-7.570^{\mathrm{ns}}$ & 15.286 \\
\hline $\mathrm{AGE}_{100 \mathrm{~kg}}$ & $-6.405^{* * *}$ & $-1.083^{\mathrm{ns}}$ & -2.981 & $-5.368 * * *$ & $1.822^{\mathrm{ns}}$ & -3.253 \\
\hline BF & $0.598^{* * *}$ & $0.005^{\mathrm{ns}}$ & 0.297 & $0.859^{* * *}$ & $0.317^{\mathrm{ns}}$ & 0.362 \\
\hline $\mathrm{BF}_{100 \mathrm{~kg}}$ & $0.113^{* * *}$ & $-0.040^{\mathrm{ns}}$ & 0.063 & $0.375^{* * *}$ & $0.351^{* *}$ & 0.109 \\
\hline
\end{tabular}

N o t e. A and D - additive and dominant model components, respectively; $2^{-1} \cdot \alpha(G \rightarrow A)-$ effect of allelic substitution; BW - body weight at the end of growing period, kg; DG1 - daily gain in the early growing period (from birth to $76.41 \pm 0.04$ days), g; DG2 - daily gain in the late growing period (from $76.41 \pm 0.04$ to $170.23 \pm 0.05$ days), g; DG - daily gain at the end of growing period, g; $\mathrm{AGE}_{100 \mathrm{~kg}}$ - the age at $100 \mathrm{~kg}$, days; BF - average actual back fat thickness measured in four points at the end of growing period, $\mathrm{mm}$; $\mathrm{BF}_{100 \mathrm{~kg}}-$ average back fat thickness calculated for the $100 \mathrm{~kg}$ body weight, $\mathrm{mm}$.

${ }^{*} \mathrm{p}<0.05 ;{ }^{* *} \mathrm{p}<0.01 ;{ }^{* * *} \mathrm{p}<0.001 ;$ ns means that estimate does not significantly deviate from 0 .

A

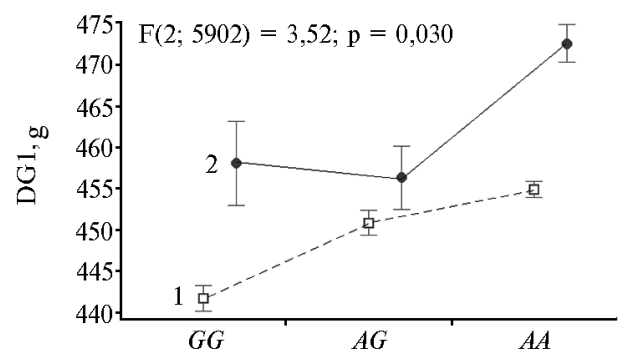

$\mathrm{C}$

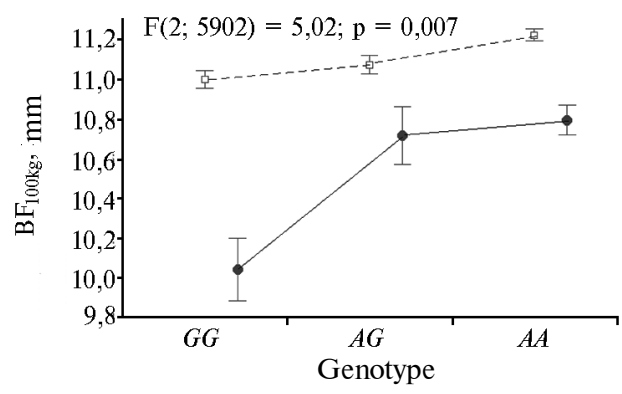

B

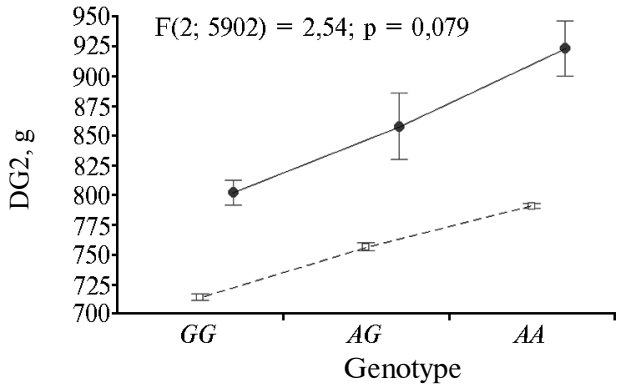

Fig. 2. Results of two-factor analysis of variance of the effect of genotype for IGF2 on gender on daily gain in the first (DG1; A) and in the second (DG2; B) growing periods, and on average back fat thickness calculated for the $100 \mathrm{~kg}$ body weight $\left(\mathrm{BF}_{100 \mathrm{~kg}} ; \mathrm{B}\right)$ in Large White pigs: 1 gilts, 2 - young boars.

All estimates of additive components were positive except for the age at $100 \mathrm{~kg}$. The values of dominant component that estimates the manifestation of inter-allele interactions within a single locus among heterozygotes (i.e. heterosis), were mostly not significantly greater than 0 . However, estimation of the dominant component of the $\mathrm{BF}_{100 \mathrm{~kg}}$ trait in young boars was significant and, for DG1, very close to the first threshold level of significance $(\mathrm{p}=0.063)$ (Table 3). Calculated estimates of the effect of allele substitution $2^{-1} \cdot \alpha(G \rightarrow A)$ in boars were much higher compared to gilts, especially with regard to DG1 $(31.57 \mathrm{~g}$ in young boars against $18.46 \mathrm{~g}$ in gilts) and $\mathrm{BF}_{100 \mathrm{~kg}}(0.109$ and $0.063 \mathrm{~mm}$, respectively) (see Table 3). That is, the extent of increase of these values at the order of $G G \rightarrow A G \rightarrow A A$ genotypes was higher in young boars compared to gilts which was confirmed by two-factor analysis of variance (Fig. 2).

Since in both gilts and boars most productivity traits had a very high degree of correlation (the correlation matrices not shown), analysis of several individual traits (univariate analysis) was replaced with the analysis of all traits (multivariate analysis). Factor load analysis (i.e. analysis of correlation coefficients of initial traits and corresponding PCs) calculated based on correlation and covariance matrices for young boars and gilts separately demonstrated that the first two PCs described most of the initial matrix variability (76.23 and $82,49 \%$ for 
young boars and gilts, respectively). PC structure was similar in the animals of different genders. First PC (PC1) was highly associated with daily gains during the late growing period (for DG2 $r=0.501$ and 0.896 in young boars and gilts, respectively) and for the entire growing period (for DG $r=0.923$ and 0.929 ; for BW $r=0.904$ and 0.982 ; for $\mathrm{AGE}_{100 \mathrm{~kg}}-0.957$ and -0.966$)$ and with $\mathrm{BF}(r=0.805$ and 0.790). Second PC (PC2), on the contrary, correlated with the values of the daily gain in the early growing period (for DG1 $r=-0.709$ and -0.769 ). Consequently, the first two PCs were two latent (relatively independent) variables that characterized the body gain in pigs within various stages of postnatal ontogenesis (PC2 in the early growing period, PC1 in the late period and over the whole growing period).

The values of additive-dominance model calculated for PC1 were completely similar in Large White pigs regardless of their gender, and the main role was played by the additive component: $\mathrm{A}=0.290, \mathrm{p}<0.001 ; \mathrm{D}=-0,064$ (in gilts) and $\mathrm{A}=0.351, \mathrm{p}<0.001 ; \mathrm{D}=0.040$ (in young boars). The effects of $2^{-1} \cdot \alpha(G \rightarrow$ A) allele substitution were also very close $(0.162$ in young boars and 0.167 in gilts).

The PC2 roles of the additive and dominant components appeared to be unequal in the pigs of different genders. Significant values for PC2 were obtained in young boars for dominant component only $(\mathrm{A}=0.085 ; \mathrm{D}=0.177$, $\mathrm{p}<0.05)$, that is, interallelic interaction on heterosis type was more pronounced in them, whereas the additive component was significant in gilts $(\mathrm{A}=0.094, \mathrm{p}<0.001 ; \mathrm{D}=-0.031)$.

For PC2, the effect of $2^{-1} \cdot \alpha(G \rightarrow \mathrm{A})$ allele substitution was not genderdependent as well (-0.005 in young boars, and 0.053 in gilts). These differences were determined by particular location of centroids for different genders and genotypes in the first two PCs (Fig. 3).

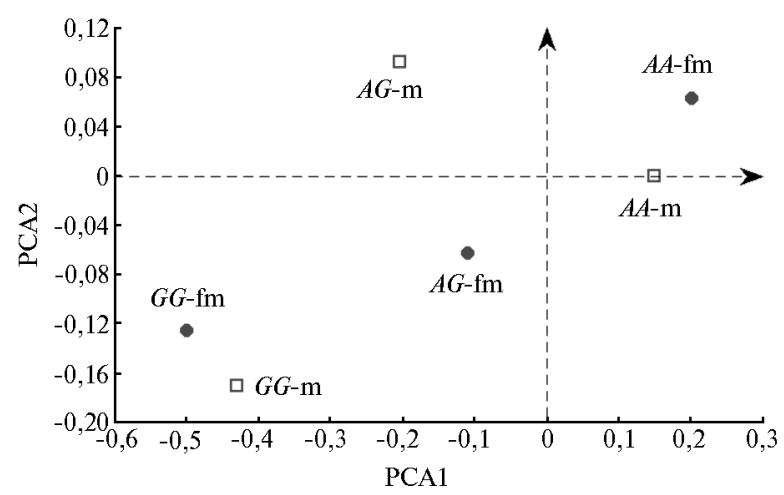

Fig. 3. Centroid sampling ordination in relation to gender and genotype for $I G F 2$ in the space of the first two principal components (PCAs) of correlation and covariance matrices for productivity values in Large White pigs: $A A, A G, G G-$ genotype for $I G F 2, \mathrm{~m}-$ young boars, fm - gilts.
One of the factors that determine the potential effectiveness of the use of DNA markers in breeding is the initial frequency of the desired allele in populations. Given the need to maintain biodiversity and the herd linear structure, as well as the fact that, as a rule, a herd is renewed by not more than $30 \%$ within a year, the maximum effect of the marker selection should be expected at a low initial incidence of the desired allele (less than $10 \%$ ), and only in the medium and long term (3-5 generations or more). With the high frequency of desired allele ( $80 \%$ or more), the marker potential may be effectuated in 1-2 generations, but its cumulative effect on the whole herd would be relatively low. The most effective marker selection in a relatively short period (2-3 generations) should be expected in case of the average frequency of the desired allele (20-70\%).

The studies of pig allele pool for IGF2 revealed differences in the distribution of allele and genotype frequencies in the animals depending on the specialization and breeding character. Maximum $A$ allele frequencies (desirable 
from the point of view of development of meat and fattening traits) were observed in pigs of meat breeds (Body, Duroc, Pietrain) and in the terminal cross characterized by the maximum selection intensity for the above traits, which is consistent with the results of foreign authors [13, 18-20]. In mother breed pigs (Large White, Landrace) and the ones produced by improving local breeds with meat breeds (Belorussian meat, Estonian bacon), intermediate $A$ allele frequencies have been recorded. In Liven pigs, $A$ allele was not found. A. Ojeda et al. [18] have also observed the lack of the above allele in some local pig breeds and in wild boar populations of different geographic origin. Based on the analysis of allele and genotype distribution for $I G F 2$ in various pig breeds, we can conclude the potential significance of this marker in breeding Large White and their close related breeds, and Landrace, Belorussian meat and Estonian bacon pig breeds.

Animals with $A A$ genotype in the 3072 IGF2 position were reported to stand out for their most lean, high daily gain and ham weight, smaller back fat thickness and better feed conversion [20, 21]. In Large White pigs, we found highly significant tendencies for the increase in the live weight gain at the end of growing period, in average daily weight gain and back fat thickness and also the younger age at $100 \mathrm{~kg}$ ranked as $G G \rightarrow A G \rightarrow A A$ genotypes for $I G F 2$, which is consistent with the studies of other authors. A significant difference of piglets of different genders has been found in their early maturity, spending feed and digestible protein per $1 \mathrm{~kg}$ of body weight gain $(\mathrm{p}<0.001)$ [22]. The superiority of males over females in their fattening productivity was found in the groups of pigs with different genotypes for MC4R [23]. In the absence of significant differences in average daily gain between gilts and young boars, M. Latorre et al. [24] found significant differences in the thickness of back fat in favor of the latter $(\mathrm{p}<0.001)$.

We first studied the effect of gender on meat and fattening pig traits depending on their genotype for IGF2. The effect of IGF2 allele substitution in boars was found to be significantly higher compared to gilts, in particular, regarding average daily gain in the early growing period (from birth to $76.41 \pm 0.04$ days) and back fat thickness calculated for the $100 \mathrm{~kg}$ body weight. As confirmed by the results of two-way analysis of variance, the intensity of the increase in these values at the order of $G G \rightarrow A G \rightarrow A A$ genotypes was higher in young boars than in gilts. We first found the different nature of the effects of genotype for IGF2 on gain values for periods of postnatal ontogenesis in pigs of different genders. The presence of two major components was shown, one of which is associated with the weight gain in the early growing period (from birth to $76.41 \pm 0.04$ days), and the second one is associated with the weight gain in the late growing period (from $76.41 \pm 0.04$ to $170.23 \pm 0.05$ days). Parameters of the additive dominant model for the main component associated with body weight gain in the late period and in the entire period of growing were similar in gilts and young boars. On the other hand, the roles of additive and dominant components differed in the pigs of different genders for the main component that characterizes the growth in the early period. Significant estimations were obtained for the dominant component in young boars and for the additive component in gilts.

Thus, we have studied the IGF2 gene polymorphism in the pigs of different breeds and crosses. Our results demonstrated the high frequency of $A$ allele and $A A$ genotype in Pietrain and Duroc breeds, as well as in the terminal cross and the Body synthetic line. In Liven pigs, $A$ allele was not found. Association studies in young pigs produced from fathers with known genotypes for IGF2 confirmed a statistically significant dependence of productivity traits on the genotype for IGF2 in both gilts and young boars. The quantitative effects of 
$I G F 2$ genotypes on meat and fat productivity in pigs, shown in our investigation, and revealed gender-dependent expression of the marker genotypes during different growing periods should be considered when developing programs of markerassisted selection that use IGF2.

\section{REFEREN C ES}

1. Marzanov N.S., Devrishov D.A., Marzanova S.N., Komkova E.A., Ozerov M.Yu., K a nt a n e n Yu. Sel'skokhozyaistvennaya biologiya [Agricultural Biology], 2011, 2: 3-14.

2. Canadian Centre for Swine Improvement. 2014 Annual Meeting, June 26, 2014: 27-28 (http://www.ccsi.ca/meetings/annual/Annualreport_2014_EN.pdf).

3. Zinovieva N.A., Kostyunina O.V., Gladyr' E.A., Bannikova A.D., Kharzinov a V.R., Larionova P.V., Shavyrina K.M., Ernst L.K. Zootekhniya, 2010, 1: 8-10.

4. Jeon J.T., Carlborg O., Törnsten A., Giuffra E., A marger V., Chardon P., Andersson-Eklund L., Andersson K., Hansson I., Lundström K., Ande rsson L. A paternally expressed QTL affecting skeletal and cardiac muscle mass in pigs maps to the IGF2 locus. Nat. Genet., 1999, 21: 157-158 (doi: 10.1038/5938).

5. N e z e r C., M o r e a u L., B rouwer s B. An imprinted QTL with major effect on muscle mass and fat deposition maps to the IGF2 locus in pigs. Nat. Genet., 1999, 21: 155-156 (doi: 10.1038/5938).

6. Chang K.C. Key signalling factors and pathways in the molecular determination of skeletal muscle phenotype. Animal, 2007, 1(5): 681-698 (doi: 10.1017/S1751731107702070).

7. V a n L a e r e A.-S. From QTL to QTN. Identification of a quantitative trait nucleotide influencing muscle development and fat deposition in pig. Doct. Thesis. Swedish University of Agricultural Sciences, Uppsala, 2005.

8. Van Laere A.-S., Nguyen M., Braunschweig M., Nezer C., Collette C., Moreau L., Archibald A.L., Haley C.S., Buys N., Tally M., Andersson G., Ge orges M., A ndersson L. A regulatory mutation in IGF2 causes a major QTL effect on muscle growth in the pig. Nature, 2003, 425(6960): 832-836 (doi: 10.1038/nature02064).

9. J ungerius B.J., Van Laer e A.-S., Te Pas M.F., van Oost B.A., Andersson L., G r o e n e n M.A. The IGF2-intron3-G3072A substitution explains a major imprinted QTL effect on backfat thickness in a Meishan $\times$ European white pig intercross. Genet. Res., 2004, 84(2): 95-101 (doi: 10.1017/S0016672304007098).

10. Estelle J., Mercade A., Noguera J.L., Pérez-Enciso M., Ovilo C., Sánch e z A., Folch J.M. Effect of the porcine IGF2-intron3-G3072A substitution in an outbred Large White population and in an Iberian $\times$ Landrace cross. J. Anim. Sci., 2005, 83: 2723-2728.

11. H e uve n H.C.M., B ove $\mathrm{nhu}$ is H., J ans s.L.G., van A re ndonk J.A.M. Efficiency of population structures for mapping of Mendelian and imprinted quantitative trait loci in outbred pigs using variance component methods. Genet. Sel. Evol., 2005, 37: 635-655 (doi: 10.1051/gse:2005019).

12. O c zkowicz M., Ty r a M., Wali nowicz K., Różycki M., Rejduch B. Known mutation $(\mathrm{A} 3072 \mathrm{G})$ in intron 3 of the $I G F 2$ gene is associated with growth and carcass composition in Polish pig breeds. J. Appl. Genet., 2009, 50(3): 257-259 (doi: 10.1007/BF03195681).

13. Yang G.-C., Ren J., Guo Y.-M., D ing N.-S., Che n C.-Y., Huang L.-S. Genetic evidence for the origin of an IGF2 quantitative trait nucleotide in Chinese pigs. Animal Genetics, 2006, 37: 179-188 (doi: 10.1111/j.1365-2052.2006.01416.x).

14. Gardan D., Gondret F., Van de $n$ Magdenberg K., Buys N., De S met S., L o u ve a u I. Lipid metabolism and cellular features of skeletal muscle and subcutaneous adipose tissue in pigs differing in IGF-II genotype. Domest. Anim. Endocrinol., 2008, 34(1): 45-53 (doi: 10.1016/j.domaniend.2006.10.001).

15. Van den Magdenberg K., Claeys E., St inckens A., Buys N., De $\mathrm{S} \mathrm{m}$ e $\mathrm{t} \mathrm{S}$. Effect of age, muscle type, and insulin-like growth factor-II genotype on muscle proteolytic and lipolytic enzyme activities in boars. J. Anim. Sci., 2007, 85(4): 952-960 (doi: $10.2527 /$ jas.2006-563).

16. Kostyunina O.V., Svezhentseva N.A., Zinovieva N.A., Dotsev A.V., Shakhin A.V., Sizareva E.I., Gladyr' E.A. Sel'skokhozyaistvennaya biologiya [Agricultural Biology], 2011, 6: 54-59.

17. Li Ch. Vvedenie $v$ populyatsionnuyu genetiku [Introduction to population genetics]. Moscow, 1978.

18. Ojeda A., Huang L.S., Ren J., Angiolillo A., Cho I.C., Soto H., Le mus Flores C., Makuza S.M., Folch J.M., Perez-Enc is o M. Selection in the making: a worldwide survey of haplotypic diversity around a causative mutation in porcine IGF2. Genet- 
ics, 2008, 178: 1639-1652 (doi: 10.1534/genetics.107.084269).

19. Ruan G.R., Xing Y.Y., Fan Y., Qiao R.M., He X.F., Yang B., Ding N.S., Re n J., Huang L.S., Xiao S.J. Genetic variation at RYR1, IGF2, FUT1, MUC13, and KPL2 mutations affecting production traits in Chinese commercial pig breeds. Czech J. Anim. Sci., 2013, 58(2): 65-70.

20. Fontanesi L., Speroni C., Buttazzoni L., Scotti E., Dall'Olio S., Nanni Costa L., Davoli R., Rus s o V. The insulin-like growth factor 2 (IGF2) gene intron3g. $3072 \mathrm{G}>$ A polymorphism is not the only Sus scrofa chromosome 2 p mutation affecting meat production and carcass traits in pigs: Evidence from the effects of a cathepsin D (CTSD) gene polymorphism. J. Anim. Sci., 2010, 88: 2235-2245 (doi: 10.2527/jas.2009-2560).

21. Loban N.A., Kostyunina O.V., Vasilyuk O.Ya., Bannikova A.D., Chernov A.S., Zinovieva N.A., Ernst L.K. Sel'skokhozyaistvennaya biologiya [Agricultural Biology], 2009, 2: 27-30.

22. G e rasi mov V.I., Pron' E.V., D a ni lov a T.N., D o n skikh T.V. Pol i produktivnost' svinei. Materialy Internet-konferentsii «Nauchnyi progress na rubezhe tysyacheletii-2007», Sektsiya Veterinariya [Proc. IT-Conf. «Millenium: progress in science-2007». Veterinary] (http://www.rusnauka.com/Page_ru.htm).

23. Klimenko A., Usatov A., Getmantseva L., Kolosov Y., Tretyakova O., Bakoev S., Kostjunina O., Zinovieva N. Effects of melanocortin-4 receptor gene on growth and meat traits in pigs raised in Russia. Am. J. Agricult. Biol. Sci., 2014, 9(2): 232-237 (doi: 10.3844/ajabssp.2014.232.237).

24. Latorre M.A., García-Belenguer E., Ariño L. The effects of sex and slaughter weight on growth performance and carcass traits of pigs intended for dry-cured ham from Teruel (Spain). J. Anim. Sci., 2008, 86(8): 1933-1942 (doi: 10.2527/jas.2007-0764). 